\title{
Monarquistas restauradores e jacobinos: ativismo político
}

\section{Pro-restoration monarchists and jacobins: political activism}

Amanda Muzzi Gomes

A primeira década da República no Brasil apresenta uma variedade de idéias e propostas políticas reveladoras de um amplo leque de estratégias de ação adotadas pelos diversos agentes históricos durante $\mathrm{o}$ aprendizado republicano. ${ }^{1}$ Foi o momento de implementação e consolidação de um novo regime, em que diversos atores políticos, individual e coletivamente, lutavam por seu quinhão opinativo e participativo, bem como pelo atendimento de determinadas demandas.

Após as duas presidências militares, exercidas pelos marechais Deodoro da Fonseca e Floriano Peixoto, tensos foram os embates ocorridos durante o go-

Amanda Muzzi Gomes é doutoranda do Programa de Pós-Graduação em História Social da Cultura da PUC-Rio e professora do curso de licenciatura em história, modalidade à distância, da PUC-Rio/UERJ (amandamuzzi@terra.com.br).

Artigo recebido em 30 de junho e aprovado para publicação em 29 de agosto de 2008.

Estudos Históricos, Rio de Janeiro, vol. 21, nº 42, julho-dezembro de 2008, p. 284-302. 
verno do paulista Prudente de Moraes, primeiro presidente civil e, também, o primeiro a ser sufragado em eleições diretas, a 28 de fevereiro de 1894. Durante a conjuntura de transição entre as presidências militar e civil muitas foram as expectativas e os alinhamentos e realinhamentos de atores diversos, bem como as disputas entre defensores de encaminhamentos políticos distintos. ${ }^{2}$

Tais disputas ocasionaram confrontos políticos peculiares entre atores históricos de posições opostas, ou seja, entre os que desejavam o afastamento daqueles até então beneficiados pelos governos militares, e mesmo uma ruptura total com o militarismo, como era o caso dos monarquistas restauradores, ${ }^{3} \mathrm{e}$ os que manifestavam um exacerbado medo da mudança, como os jacobinos. Além do temor de uma suposta restauração monárquica, os jacobinos receavam perder as modestas, mas até então mais elevadas, posições conquistadas.

Desde as negociações para a apresentação da candidatura de um civil à presidência, os restauradores esperavam ver inaugurada no país uma "nova era", a da extinção da "ditadura militar", como definiam o governo de Floriano, e de suas conseqüências, como entendiam, por exemplo, a instabilidade cambial, que atrapalhava seus negócios; o alijamento de ilustres homens do Império das posições de relevo, tendo como contrapartida o favorecimento, na ocupação de cargos públicos, de homens novos sem tradições familiares; ou as benesses concedidas aos militares do Exército e aos simples militaristas desordeiros e oportunistas, como caracterizavam os jacobinos.

Não obstante a orientação conciliadora do primeiro governo civil, posta em marcha com certa cautela desde o início dos trabalhos administrativos, e o posicionamento moderado de Prudente, os monarquistas restauradores reclamavam que os efeitos da "ditadura militar" ainda não haviam sido abolidos; que eram perseguidos pelos florianistas e atacados pela reativação de seus discursos antimilitaristas; que ainda não haviam sido repostos em suas posições; que os católicos continuavam prejudicados pela separação en tre Estado e Igreja, entre outras queixas.

Com a intensificação de suas reivindicações, durante o segundo semestre de 1895 os monarquistas restauradores superaram algumas diferenças políticas vigentes desde o período imperial, que em parte vinham de sua divisão em liberais e conservadores, e reuniram-se de forma até então inaudita. Tais ativistas encontraram então condições propícias para sua arregimentação política. O governo Prudente de Moraes foi, de fato, o primeiro a lhes propiciar liberdade para uma aglutinação mais organizada, até mesmo pelo fim de uma administração governamental sob sucessivas prorrogações do estado de sítio, como transcorrera boa parte do exercício presidencial de Floriano Peixoto. Além disso, foi permitido o retorno de monarquistas emigrados que se encontravam na Europa. 
Assim, durante o segundo semestre de 1895, Afonso Celso e Eduardo Prado publicaram no jornal Commercio de S. Paulo, de propriedade de César Ribeiro, vários artigos de cunho doutrinário conclamando a aglutinação não apenas dos monarquistas, mas dos descontentes em geral, inclusive os adesistas desiludidos. Da parte do governo não houve iniciativa para o controle dessa arregimentação e tampouco o estabelecimento de algum tipo de censura às publicações.

Os convivas do banquete político de 15 de outubro - organizado por Eduardo Prado e Rafael Correia em comemoração do aniversário de D. Pedro de Alcântara - resolveram por acordo, embora não unânime, estruturar um partido monarquista. O toque de alarme foi logo alastrado pela imprensa republicana, porém não despertou reação do novo governo. Propositalmente no dia do sexto aniversário da proclamação da República, os restauradores sentiram-se seguros para lançar o "Manifesto do Partido Monarquista de S. Paulo", de autoria de João Mendes de Almeida, que só não alcançou o efeito condensador esperado por seus signatários devido ao acentuado teor religioso. Boa parte da imprensa republicana, inclusive a jacobina, reagiu através das publicações regulares e dos panfletos, anônimos e assinados por pseudônimos. Mas os restauradores prosseguiram com sua politização, estabelecendo as bases de atuação do Partido Monarquista na sua primeira reunião, realizada a 3 de dezembro na casa do redator do manifesto. Várias iniciativas foram tomadas pelos ativistas, sobressaindo-se a aquisição, por Eduardo Prado, do jornal Commercio de S. Paulo para que se tornasse o órgão do partido (Janotti, 1986: 85-160).

Entusiasmados com a iniciativa dos correligionários de São Paulo, os restauradores da capital federal criaram o Diretório Monarquista do Rio de Janeiro, enviaram uma carta de saudação ao diretório paulista e lançaram um manifesto, intitulado "À Nação Brasileira", publicado no fornal do Commercio de 12 de janeiro de $1896 .{ }^{4}$ Estava dada a partida para a organização política e propagandista dos monarquistas da capital da República. Apesar das discordâncias acerca das estratégias para alcançar a restauração monárquica, os restauradores do Rio de Janeiro e de São Paulo engajaram-se cada vez mais na causa comum. Ainda em janeiro de 1896, surgiu o "Centro dos Estudantes Monarquistas de São Paulo", por iniciativa de jovens da Faculdade de Direito. No dia 19, foi lançado como órgão dessa associação o jornal Auctoridade, com o qual mais tarde $O$ facobino e $O$ Nacional travariam acalorados debates político-discursivos. Na capital, surgiram publicações expressamente restauradoras, como os jornais Rio de faneiro e $O$ Município, além de prosseguirem as folhas monarquistas já existentes, como $O$ Apostolo, em circulação desde 1866, e O Império, desde 1885. Os mais renomados ativistas restauradores do Rio, que compunham também o grupo mais coeso da cidade, resolveram, por iniciativa de Carlos de Laet e seus amigos mais próxi- 
mos, fundar um jornal sugestivamente intitulado Liberdade, cujo primeiro número saiu a lume no dia 4 de maio. ${ }^{5}$

Através de seus órgãos na imprensa, os restauradores não faziam apenas propaganda favorável ao restabelecimento monárquico, até mesmo porque lhes faltava a anuência efetiva dos membros da família imperial para esse propósito, e havia ainda suas próprias discordâncias acerca de questões práticas para conseguir a restauração. Ainda que continuassem desejando subverter as instituições políticas vigentes, buscavam imiscuir-se na vida política republicana. Assim, faziam de seus jornais órgãos de denúncia, por exemplo, da situação de favorecimento do Exército em detrimento da Marinha, arma mais associada à Monarquia. E também tomavam partido em relação às questões candentes da conjuntura, fazendo pressão a favor do reatamento das relações diplomáticas com Portugal, da pacificação do sul do país e da anistia para os insurgentes da Armada e da Revolução Federalista.

Fora justamente a partir da Revolta da Armada que os jacobinos haviam alcançado proeminência política, mormente no cenário da capital. A designação jacobinos já era utilizada pelo menos desde os últimos anos do governo monárquico, com a acepção de "republicanos radicais", especialmente nas referências aos partidários do propagandista republicano Antonio da Silva Jardim, que usava praças e teatros para pronunciar suas conferências e discursos políticos. No início do século XX, o termo ainda teria uma relativa utilização e voltaria a ser empregado, como sinônimo de "desordeiro", principalmente quando da ocorrência da Revolta da Vacina em 1904, durante a presidência de Rodrigues Alves. Foi, entretanto, no governo de Floriano Peixoto que o termo adquiriu um sentido ímpar, ao ser aplicado aos jovens que se alistaram voluntariamente nos batalhões patrióticos quando da irrupção da Revolta da Armada, a 6 de setembro de 1893. Esses jovens eram os mais veementes florianistas, os propalados "amigos do marechal Floriano". ${ }^{6}$ E esse era o sentido atribuído à palavra tanto pelos autodenominados jacobinos quanto por seus desafetos. Foi desse ano de 1893 até 1897 - quando ocorreu a repressão aos implicados no atentado à vida de Prudente de Moraes, ocasionando a dispersão política dos jacobinos - que teve vigência o "jacobinismo", movimento político cuja inspiração maior era o "florianismo" (Hahner, 1976; Queiroz, 1986; Muzzi, 2006).

Muitos dos jacobinos ou jovens "patriotas" que combateram espontaneamente ao lado do governo em 1893 foram galardoados após o término da Revolta da Armada em reconhecimento aos seus serviços, por meio da concessão de patentes honorárias e da nomeação para cargos públicos. Quando ocorreu a vitória das forças "legalistas" sobre os revoltosos da Armada, em 13 de março de 1894, o sul do país ainda se encontrava convulsionado pela Revolução Federalista, desencadeada em fevereiro de 1893 em razão da disputa entre líderes políticos 
locais pelo exercício do governo do Rio Grande do Sul. Por esse motivo, mesmo com o fim da Revolta da Armada, o governo de Floriano não dissolveu os batalhões patrióticos criados em caráter provisório, continuando seus membros a receber o soldo e, no caso dos que combatiam contra os federalistas sublevados, também as vantagens de campanha. Dessa maneira, não somente o "florianismo" desses combatentes manteve-se forte, como ainda recrudesceu o senso da missão que se atribuíam, de salvaguarda das instituições republicanas.

A defesa do governo de Floriano Peixoto, o "Salvador da República", diante da intenção de restauração monárquica que os jacobinos tributavam aos revoltosos da Armada passou a ser o objetivo que lhes deu entusiasmo e impulso de ação para criar, em setembro de 1894, seus primeiros órgãos na imprensa: $A$ $B o m b a$ (que a partir de janeiro de 1895 se chamou O Nacional) e Ofacobino, na cidade do Rio de Janeiro, onde se localizavam os militantes mais expressivos. $O$ Nacional e O facobino ofereceram apoio a publicações de mesmo cunho que começaram a circular no interior do Estado do Rio e em outros estados, como $O$ Nativista, na cidade de São Paulo. Apesar das variações e mudanças de intensidade dos pontos que compunham as propostas dos jacobinos, ao longo dos seus quatro anos de ativismo político destacaram-se, entre outros, a defesa de seus interesses corporativos, a demanda de manutenção de uma ordenação governamental republicana militarista e militarizada e, em contrapartida, o antimonarquismo e o ataque aos monarquistas restauradores, que chamavam de "sebastianistas". Esses componentes de seu ideário político eram expressos de modos distintos por um e outro "subgrupo" jacobino, além de se mesclarem em seus discursos de modo variável a outros objetos de defesa e alvos de ataque, como o nacionalismo e o antilusitanismo.

A inflexão efetuada pelo início da execução do plano político do governo de Prudente de Moraes, consoante com um projeto político-administrativo divergente em relação ao de seu antecessor, paulatinamente obliterava a ordenação militarista recebida como legado. Desse modo, tornava desnecessária a atuação de numerosos batalhões patrióticos, compostos de voluntários, para a sustentação do regime republicano e do governo no poder. A ênfase na necessidade de preservação das milícias cívicas e o apelo aos valores castrenses foram então acionados pelos jacobinos como uma estratégia de sobrevivência numa conjuntura em que o regime republicano estava palmilhando caminhos que tornavam os batalhões patrióticos e, por extensão, seus integrantes, dispensáveis. Assim, a partir de dezembro de 1894, após as primeiras medidas governamentais, especialmente as que alteravam a situação de favorecimento dos batalhões patrióticos e do Exército, O Nacional e O Facobino passaram a destinar muitas colunas a ataques ao governo civil de Prudente de Moraes, empossado a 15 de novembro. 
Inicialmente, em seu primeiro movimento de oposição a Prudente de Moraes, os jacobinos basearam suas reivindicações nas deliberações antimilitaristas do governo, mormente nos licenciamentos e dissoluções graduais dos batalhões patrióticos, caracterizando-se assim aquele momento de oposição pela defesa dos seus interesses corporativos. Já o segundo momento de oposição a Prudente foi marcado pelo temor à mudança, ou seja, à restauração monárquica, e teve como fundamento o ineditismo da atuação aglutinadora e da atividade propagandista dos monarquistas restauradores (Muzzi, 2006: 47-126). A falta de qualquer iniciativa governamental para conter a organização política dos restauradores foi entendida pelos jacobinos como uma prova de fraqueza do novo governante e de uma suposta simpatia pelo monarquismo.

Alguns monarquistas renomados e influentes, como o visconde de Ouro Preto, labutavam pelo restabelecimento monárquico através da correspondência trocada com monarquistas ainda emigrados e com membros da família real, principalmente a princesa Isabel, que mantinha um secretário encarregado de responder às cartas que recebia. Para os jacobinos, a superestimação dessas "maquinações" urdidas no país e no exterior constituía um meio de demonstrar que os "patriotas legalistas" faziam-se ainda necessários na sustentação das instituições republicanas. Como alegavam, a intensidade da propaganda restauradora e a rede de contatos estabelecida entre seus partidários permitiam a previsão de que, a qualquer momento, pudesse ocorrer um golpe de Estado.

$\mathrm{O}$ “monstro" da restauração era retratado em dimensões exageradas pelos jacobinos, o que fazia com que buscassem intensificar seus meios de ação e veículos de difusão de idéias. Além disso, eles imbuíram-se do dever de cumprir as derradeiras recomendações do marechal Floriano, expressas no seu "Testamento político". O documento não era mais do que uma longa carta dirigida pelo ex-presidente em seus últimos dias de vida, quando já se encontrava em Divisa, onde faleceu, a uma comissão de moços patriotas que o fora visitar, mas a qual não pudera receber em razão da gravidade de seu estado de saúde. ${ }^{7}$ Após a morte do marechal, os aconselhamentos contidos no "Testamento" transformaram-se em dogmas para os jacobinos. Em razão da leitura ortodoxa que fizeram dos preceitos de Floriano, entenderam ser insuficiente a atividade exercida principalmente através da imprensa para conter o suposto avanço restaurador, e buscaram ampliar seu leque de atividades.

Deocleciano Martyr (criador e redator-chefe de O Facobino, e também ex-integrante do Batalhão Tiradentes) e seus prosélitos intensificaram sua atuação tornando mais freqüentes as reuniões e as atividades propagandistas do Clube dos Jacobinos e do Partido Jacobino, dos quais Martyr era presidente. Já os redatores de $\mathrm{O}$ Nacional (em boa parte, integrantes e ex-integrantes do Batalhão Tiradentes) estreitaram o contato com os jacobinos de outros estados e cidades, 
mormente com os correligionários da capital paulista, aumentaram suas participações nos meetings de protesto e estimularam o comandante Vicente Martins a reabrir o alistamento do Batalhão Tiradentes. A redação de $O$ Nacional tornou-se local de inscrição dos voluntários e sede da comissão de sindicância do batalhão, composta por alguns redatores do periódico.

Todavia, de maior significação foi a organização do Partido Republicano Nacional, para cujo esforço de criação os jacobinos buscaram e contaram com o auxílio, entre outros, dos deputados Nilo Peçanha e Franco Carvalho, do senador João Cordeiro e do literato Raul Pompéia. ${ }^{8} \mathrm{O}$ manifesto do partido, todavia, só foi publicado a 3 de março de 1896, postergado, entre outros motivos, pelo suicídio de Raul Pompéia no dia de Natal. Por conseguinte, o manifesto foi redigido pelo secretário e redator de $\mathrm{O}$ Nacional, Lindolpho Azevedo. ${ }^{9}$ Foi considerada como data de fundação do partido o dia 12 de fevereiro de 1896, com regulamento emitido em 18 de abril.

Desde o início seus organizadores se preocuparam em captar o apoio de figuras ilustres do cenário político, até para que a organização política embrionária pudesse sobreviver. Mais adiante, buscaram o apoio de cidadãos notórios, como os bacharéis, padres e altos oficiais das duas armas. Em maio o diretório central do PRN já era constituído pelos seguintes membros: presidente - Jeronyimo Gonçalves (o comandante da esquadra legal vitoriosa no combate à Revolta da Armada); vice-presidente - Dr. Martiniano Brandão; secretário - Lindolpho Azevedo; major Antonio de Moraes Rego; Julio da Silveira Lobo; Dr. Carlos Antonio de Paula Costa; padre Dr. José Maria da Trindade; capitão Servilio José Gonçalves e Annibal Mascarenhas. ${ }^{10}$

Devido aos esforços de atração de figuras conhecidas, com o tempo o PRN foi se tornando cada vez mais heterogêneo. Ainda assim, de modo semelhante aos discursos do momento de criação do partido, seus membros ainda explicitavam o ressentimento pela perda de influência e apeamento de posições durante a presidência civil, bem como a superestimação do "perigo" representado pelo regresso monárquico para as instituições republicanas, ainda mais depois da eclosão do movimento de Canudos. ${ }^{11}$

Em um jogo de ação e reação, a cada avanço no tabuleiro político, como efeito de uma nova jogada do adversário, jacobinos e restauradores preparavam-se para o rebate, inclusive em razão das notícias e dos boatos alardeados que serviam como incitamento aos jogadores.

Ao longo dessa conjuntura de transição, exacerbou-se a oposição a Prudente de Moraes oriunda de diversos focos: dos monarquistas, que cada vez mais se tornavam restauradores; dos clérigos e jovens católicos, cujas demandas eram em boa parte esposadas pelos restauradores; dos florianistas em geral e demais beneficiados pelo governo do marechal Floriano, que cada vez mais se identifi- 
cavam em interesses com os jacobinos; dos militares e, particularmente, dos jovens da Escola Militar, alguns dos quais se aproximavam dos jacobinos; dos alunos acadêmicos, inclinados a se unirem aos restauradores ou aos jacobinos e, também, dos integrantes da chamada "ala radical" do Partido Republicano Federal (PRF), pelo qual Prudente havia sido eleito.

Algumas resoluções que emergiram diretamente do gabinete presidencial, bem como outras que foram resultado de deliberações congressuais, davam margem a interpretações dicotômicas. Nesse caso incluíam-se, em especial, as que representavam uma espécie de solução de compromisso para contemporizar com as opiniões mais extremas, como, por exemplo, a concessão de anistia ampla aos civis, mas restrita aos militares que haviam participado da Revolta da Armada e da Revolução Federalista. Por medidas governamentais como essas, Prudente era visto como um presidente suspeito pelos jacobinos e pouco temido e respeitado pelos restauradores. Quando seus opositores não viam ambigüidade em suas ações, julgavam estar frente ao pior: o desgoverno. Para os jacobinos, tal situação faria com que os "subversivos da República" concretizassem a restauração monárquica. Já para os restauradores, o desgoverno possibilitaria o retorno da ditadura militar, supostamente tão aspirada pelos "radicais da República".

Assim, em suas jogadas políticas, restauradores e jacobinos marcavam sua posição enquanto grupos de pressão sobre o governo federal. Isso não significa que fossem eclipsadas as clivagens existentes no interior tanto do grupo dos restauradores como dos jacobinos. Tanto em suas rusgas como na busca de apoio de outros atores políticos, restauradores e jacobinos buscavam demarcar seu território de influência, disputavam a autoridade da palavra e tentavam realçar pontos em comum com outros contemporâneos. Ainda que essas ampliações dos seus respectivos leques de ação e atividades propagandistas lhes tenham sido úteis, pois a cada dia os dois grupos conseguiam mais adeptos para suas fileiras, em pouco tempo seus respectivos ativismos foram extirpados.

$\mathrm{O}$ ambiente social de inflamação do sentimento republicano e nacionalista facilitou a repressão aos restauradores. Em São Paulo, a efervescência motivada pela candente questão dos "protocolos italianos", principalmente após os distúrbios de fins de agosto de 1896, contribuiu para o desenlace fatal às associações políticas, imprensa e partido restauradores. No dia 30 de outubro, uma escolta policial invadiu o sobrado onde funcionavam o Centro Monarquista (recém-criado pelo grupo "mendista" após a cisão dos restauradores daquele estado) e o Centro de Estudantes Monarquistas, e os fechou. As oficinas do jornal Auctoridade, estabelecidas no mesmo local, também foram interditadas. No dia seguinte, foi dissolvida uma reunião dos "pradistas" na casa de Augusto de Queiroz (Janotti, 1986: 126-134). ${ }^{12}$ 
A partir de 11 de novembro, o governo federal passou a ser chefiado interinamente pelo vice-presidente Manuel Victorino, por causa da demorada convalescença cirúrgica de Prudente de Moraes. Os republicanos de diversos matizes encararam com bons olhos a substituição, entre eles Deocleciano Martyr, o mais aguerrido militante jacobino, que tanto havia criticado o "adesista" Victorino. Mas já em janeiro de 1897 começaram os rumores de que Prudente reassumiria a presidência. ${ }^{13}$ Deocleciano Martyr passou a concitar o Exército, a parcela republicana da Armada, a mocidade e os "republicanos extremados" para que se unissem no impedimento da volta de Prudente, não encontrando, porém, adeptos para essa implícita conclamação golpista. Prudente de Moraes reassumiu a presidência no dia 4 de março, sem qualquer comunicação oficial prévia a Victorino e seu ministério, o que ocasionou um enfurecimento relativamente generalizado, em razão da aceitação que Victorino vinha conquistando. ${ }^{14}$ A partir de então, os incidentes político-sociais assumiram uma coloração mais escura aos olhos dos contemporâneos.

Muitos estavam irritados com o retorno de Prudente à chefia do Executivo quando se noticiou, em 7 de março, o fracasso da terceira expedição enviada a Canudos e a morte de seu comandante florianista, o coronel Antonio Moreira César. Além disso, era de conhecimento público, na ocasião, o processo movido pelo coronel Gentil José de Castro (proprietário dos jornais monarquistas Liberdade e Gazeta da Tarde) contra o jornal República, órgão do PRF, em razão das acusações que lhe eram feitas, como a de ter enviado armas e munições aos conselheiristas (Janotti, 1986: 134-138). E vários integrantes do Clube Militar haviam-se reunido na noite do dia 6 , em sessão que tratou da derrota da terceira expedição, tendo-se destacado fluentes oradores florianistas e jacobinos, como Thomaz Cavalcanti, Costa Ferraz e Carlos Costa. ${ }^{15}$

Nesse clima de ebulição político-social, não houve qualquer contenção de furor por parte de jacobinos e outros republicanos, que no próprio dia 7 se aglomeraram na rua do Ouvidor, conclamando logo no início da tarde um meeting para o largo de São Francisco. Entre os manifestantes encontravam-se Deocleciano Martyr e João Clapp, respectivamente presidente e vice-presidente do Clube dos Jacobinos, e os parlamentares Thimotheo da Costa, João Cordeiro e Nilo Peçanha. Tão intenso era o grau de agitação que o ajudante-general do Exército impediu a realização do meeting.

O grupo contestador não se dissipou e ainda foi engrossado por outros indignados. Em um suposto ímpeto de desagravo, os manifestantes dirigiram-se às tipografias e redações dos jornais Gazeta da Tarde, Liberdade e O Apostolo, destruindo os estabelecimentos e retirando os materiais encontrados, com os quais fizeram uma fogueira no largo de São Francisco. Em seguida, dirigiram-se às redações de vários jornais, de cujas sacadas falaram seus redatores principais e al- 
guns congressistas florianistas: da Republica, discursaram Alcindo Guanabara, Belisário de Souza e Frederico Borges, ao passo que, da Cidade do Rio, falaram Paula Ney e até o antiflorianista José do Patrocínio. Estimulados pela ardência dos discursos, os manifestantes rumaram para a residência de Gentil de Castro, que estava em Petrópolis, tendo sido sua casa invadida e depredada.

No mesmo dia 7, a capital de São Paulo também foi palco de manifestações, com a destruição da redação do jornal monarquista Commercio de S. Paulo, e a preventiva proteção policial à casa de João Mendes de Almeida. ${ }^{16}$

No Rio, as agitações prosseguiram no dia seguinte. Houve uma reunião popular no Clube Militar pela manhã, um meeting no largo de São Francisco à tarde, seguido das costumeiras orações inflamadas pronunciadas por redatores e políticos das sacadas dos jornais. Gentil de Castro, o visconde de Ouro Preto e o filho deste, Carlos Afonso de Assis Figueiredo, retornaram de Petrópolis a fim de aferir as ocorrências. Ao chegar à cidade e tomar conhecimento dos gritos ecoados de "mata os monarquistas", resolveram regressar. Quando se encontravam no trem esperando a partida, foram atacados por um grupo de aproximadamente 30 homens. Após os insultos verbais e tiros trocados, Gentil de Castro foi atingido mortalmente, conseguindo escapar os outros dois restauradores. Os 10 indivíduos indiciados como autores do crime mais tarde foram absolvidos (Janotti, 1986: 134-143; Queiroz, 1986: 47-50).

Ao custo da agressividade, foi desbaratada a atividade política e propagandista dos restauradores no Rio e também em São Paulo, onde já havia sido efetuada a repressão policial e oficial. Alguns líderes restauradores, como o próprio Ouro Preto, ainda tentaram inutilmente, com a apresentação de Gentil de Castro como o mais novo candidato a herói do seu panteão cívico, restabelecer as atividades. Todavia, a maioria dos militantes ficou atemorizada diante da situação de insegurança que Joaquim Nabuco descreveu como "terror jacobino" (Janotti, 1986: 147).

O ministro do Interior, Amaro Cavalcanti, ofereceu proteção aos monarquistas mais conhecidos, como Afonso Celso, Ouro Preto, João Alfredo e Joaquim Nabuco. Outros, como João Scaligero Maravalho, redator-chefe de $O$ Apostolo, e Angelo Agostini, diretor e desenhista de D. Quixote, pediram proteção às autoridades policiais. Já Eduardo Prado, temendo pela sua vida em razão das perseguições sofridas nas ruas de São Paulo, deixou o país rumo à Europa. Em razão dos boatos de que haveria mais ataques a jornais da capital, forças policiais postaram-se nos escritórios de D. Quixote, Fornal do Brasil, Fornal do Commercio e até da republicana Gazeta de Noticias. ${ }^{17}$

Desde a propagação das notícias do possível retorno de Prudente e principalmente após sua reinstalação na chefia do Executivo e as agitações subseqüentes à notícia da morte de Moreira César, Deocleciano Martyr cada vez mais 
passou a falar em vindita nacional. Concitava a mocidade republicana e os militares a empunharem armas em prol da República e da tão alegada dignidade das Forças Armadas. ${ }^{18}$ Aos jovens voluntários dos batalhões patrióticos, principalmente do Batalhão Tiradentes e do Batalhão Acadêmico, fez um chamamento especial: deveriam estar a postos para tomar suas trincheiras na hora em que soasse o clarim da destituição do presidente da República. ${ }^{19}$ Eram claros os seus incitamentos a um golpe de Estado que, da parte dos voluntários dos batalhões, não foi ouvido.

Em pouco tempo, contudo, Martyr encontrou o indivíduo perfeito para aliciar a seus planos conspiratórios. Em fins de agosto, na redação de O Facobino, $o$ ativista recebeu um visitante que lhe seria muito proveitoso: Marcellino Bispo de Mello, um anspeçada do Exército de 22 anos, natural de Alagoas, que havia sentado praça em um batalhão de Pernambuco no início do ano anterior. $\mathrm{O}$ jovem militar, leitor assíduo de O Facobino, cultuava Martyr. Facilmente, o jovem deixou-se guiar pelo palavreado fácil de Martyr, cuja linguagem escrita já o inebriava. Este habilmente lhe afirmou que Prudente se utilizava do movimento de Canudos para restabelecer a Monarquia e perseguia os militares em geral, todos os florianistas e também os alagoanos, como ele, Marcellino, e o falecido marechal Floriano Peixoto.

Entretanto, Marcellino Bispo era apenas a ponta da lança, o rosto assassino que meses depois apareceria estampado nas capas dos jornais, enfim, a figura mais aparente de um plano urdido por Martyr e muitos outros jogadores políticos adversários de Prudente, inclusive eminentes figuras oficiais, como Francisco Glycerio e Manuel Victorino Pereira. Foi no próprio recinto da Câmara dos Deputados que Martyr conferenciou pela primeira vez com Glycerio, nos últimos meses o líder da oposição parlamentar ao governo. No salão do Senado, duas vezes Martyr conversou com o vice-presidente da República, que lhe pediu que escrevesse uma carta sobre o andamento da conspiração, documento que o maquinador redigiu sobre a mesa do jacobino capitão Servilio Gonçalves, no $1^{\circ} \mathrm{Re}-$ gimento de Cavalaria. Apesar do livre trânsito de Martyr nos recintos oficiais para as confabulações, era na sala de redação de $O$ Nacional e na farmácia de Umbelino Pacheco (capitão reformado da Brigada Policial e diretor-fiscal do Clube dos Jacobinos) que ocorriam as reuniões da comissão encarregada do planejamento tático do atentado à vida do presidente da República. Eminentes políticos do governo faziam parte dessa comissão ou participavam dessas sessões. $\mathrm{O}$ deputado Irineu Machado, por exemplo, forneceu o dinheiro pedido por Martyr para a compra da arma do crime, que foi adquirida por José de Souza Velloso e entregue a Marcellino. O deputado João Cordeiro foi um dos primeiros a aprovar a eliminação física de Prudente como solução para a tensa situação política do país e o primeiro a ler a carta de Martyr escrita a Victorino sobre a conspiração. O 
deputado Alexandre José Barbosa Lima antecipou-se na aprovação do primeiro plano urdido. Outros projetos atentatórios a Prudente foram tramados por outros agentes sociais de forma paralela e independente deste, que foi o único a chegar a ser posto em prática. Na verdade, a arma deveria ter sido disparada por Marcellino desde setembro nas diversas ocasiões em que Prudente viera a público, como na parada do dia da Independência, mas o jovem aliciado por Martyr nada via ou simplesmente hesitava (Queiroz, 1986: 64-72).

No dia 5 de novembro, na cerimônia de recepção ao general Silva Barbosa e de dois batalhões que haviam participado da expedição vitoriosa a Canudos, ao cruzar o pátio do Arsenal de Guerra, Prudente de Moraes foi alvejado por Marcellino Bispo. Ao apertar o gatilho direito da garrucha de dois canos, que estava sem munição, Marcellino, além de não atingir Prudente, ainda deu tempo para que este pudesse abandonar o local. Na agitação subseqüente ao disparo sem munição, o anspeçada deu quatro facadas no ministro da Guerra, marechal Carlos Machado Bittencourt, que faleceu dez minutos depois, e ainda feriu no abdômen o coronel Luiz Mendes de Moraes. ${ }^{20}$ Sem que ainda o soubessem, com esse atentado e o assassinato de um ministro, os jacobinos estavam fadados sair do cenário político.

A indignação diante da mão assassina do anspeçada e dos conspiradores tomou conta dos habitantes da capital. Na madrugada do dia 6, em desagravo, as tipografias de O Facobino, Republica e Folha da Tarde - tendo esta última começado poucos meses antes sua oposição sistemática a Prudente - foram atacadas e seus bens foram danificados, ao passo que $O$ Paiz foi defendido pelos próprios funcionários. Pela manhã, houve manifestação de protesto em frente à Câmara. O deputado prudentista José Joaquim Seabra tentou acalmar a multidão dizendo que o jacobinismo seria extirpado. A residência de Victorino, a seu pedido, passou a ser guardada por uma força da brigada policial. Enquanto romarias eram feitas ao palácio do governo, para felicitar Prudente por ter escapado vivo do atentado e dar-lhe os pêsames pela morte de seu ministro da Guerra, a rua do Ouvidor era palco de motins e agitações.

No mesmo dia 7, os primeiros conspiradores foram presos: os capitães honorários Deocleciano Martyr e Joaquim Freire e o deputado Medeiros e Albuquerque. ${ }^{21}$ No dia seguinte, Prudente de Moraes enviou mensagem ao Congresso solicitando a declaração do estado de sítio. Aprovado o pedido pela Câmara a 11 e pelo Senado a 12 de novembro, pela primeira vez foi assinado, pelo primeiro presidente civil, um decreto de estado de sítio para o Distrito Federal e a comarca de Niterói, a vigorar por 30 dias. ${ }^{22}$ Por sucessivas prorrogações, assim Prudente de Moraes governou até 23 de fevereiro do ano seguinte, possibilitando ao governo civil eclipsar as manifestações nas vias públicas e si- 
lenciar os jornais potencialmente incendiários. No mesmo dia em que o presidente e o ministro da Justiça e Interior sancionaram o decreto, o plano de fuga da prisão de Deocleciano Martyr foi descoberto. O coronel Travassos percebeu que o aliciador de Marcellino tramava escapar com Joaquim Freire do quartel da brigada policial iludindo os vigilantes. ${ }^{23}$

Inicialmente Martyr negou sua participação, mas nos depoimentos posteriores não apenas confessou o crime como delatou um a um todos os envolvidos no plano atentatório à vida do presidente da República. Os parlamentares e o vice-presidente, assim que foram incluídos nos inquéritos, trataram de protestar inocência. No caso dos primeiros, entre os que não foram detidos, alguns, como Irineu Machado, deixaram de comparecer às sessões do Congresso; outros, como Torquato Moreira, do Espírito Santo, retornaram a seus estados natais, para fugir às punições e à sanha dos indignados nas ruas da capital. No Congresso, a "ala" dos antigos "radicais" do PRF ficou combalida.

Os inquéritos e processos transcorreram sob segredo de justiça. As medidas punitivas foram o desterro, principalmente para Fernando de Noronha, e a prisão dos implicados no atentado, mesmo que não comprovadamente culpados. Além disso, ainda em novembro foram cassadas as honras militares conferidas em diferentes momentos do ano de 1894 aos ex-voluntários de batalhões patrióticos e apoiadores de Floriano implicados na conspiração, como as de Deocleciano Martyr, Benjamin Constant Filho, Alcindo Guanabara e Joaquim Augusto Freire. A condenação de Martyr e de alguns dos acusados significou não apenas a punição pelo seu crime de conspiração, mas principalmente a dissolução da própria atuação política dos jacobinos, quer fossem seus acólitos ou não, pois o proeminente jacobino havia deslegitimado a oposição jacobina a Prudente ao desviá-la do terreno da legalidade. A 24 de fevereiro de 1898, Marcellino Bispo foi encontrado morto com pesos amarrados aos pés. Apesar da declaração oficial ter atestado morte por enforcamento, houve rumores de que ele havia sido assassinado. Ao longo do ano, todos os depoentes arrolados nos inquéritos, a começar por Martyr, desmentiram-se, alegando ter sofrido coação, sob a forma de ameaças e torturas, antes de seus depoimentos.

Para os jacobinos o golpe foi duro, tanto que nunca mais se arregimentaram. Principalmente para os que se haviam incorporado a algum batalhão patriótico, desfazia-se qualquer vestígio de esperança de que pudessem voltar a auferir ou manter suas vantagens corporativas. Não havia mais por que ou como lutar pela conservação dos batalhões, pois os que haviam sido criados recentemente ou reorganizados para combater na Bahia foram dissolvidos após a vitória da quarta expedição sobre o movimento de Canudos. A 29 de novembro, através do cumprimento do aviso emitido pelo novo ministro da Guerra, foi dissolvido o maior dos batalhões patrióticos: o Batalhão Tiradentes. ${ }^{24}$ 
A suspensão das garantias constitucionais trouxe como conseqüência principal o auto-silenciamento da imprensa oposicionista, a auto-abstenção de reunião de republicanos oposicionistas, e ainda permitiu o fechamento do Clube Militar. Como mencionado, muitos restauradores já haviam abandonado o país, e os que ficaram desde março já não mais se manifestavam. Outros, como os trabalhadores, os religiosos católicos e a mocidade estudantil e acadêmica, também diminuíram o ímpeto de suas propagandas políticas. O desfecho mais trágico, todavia, foi mesmo para os jacobinos, e não apenas para os que amargaram anos de detenção. Não havia mais circunstância histórica nem audiência para as exposições das mesmas propostas, tanto que os que voltaram à arena política nos anos seguintes passaram a levantar outros princípios e defender outras idéias (Muzzi, 2006: 129-131).

Restauradores e jacobinos eram atores que movimentavam o cenário político, seja através da pressão sobre o governo, seja através das conexões e enfrentamentos em relação a outros agentes. Eles dialogavam, porfiavam e/ou se articulavam com outros agentes sociais do período que também possuíam motivações políticas e defendiam suas propostas, como republicanos em geral, outros republicanos florianistas além dos jacobinos, católicos ativistas, militares militaristas, militares civilistas, jornalistas em geral, literatos, membros do governo, operários e trabalhadores.

Eles possuíam modalidades de ação comuns, mas também distintas, pois, por exemplo, diferentemente dos restauradores, os jacobinos utilizavam com certa freqüência as ruas e praças como loci de atividades, e não se notabilizaram como os restauradores pela produção de obras intelectuais de fundo político. Desse modo, as suas práticas induzem à reflexão acerca de seus distintos lugares enquanto atores políticos e de seus diferentes posicionamentos sociais.

A criação de jornais propagandistas da pequena imprensa; as manifestações espontâneas de protesto nas ruas mais estratégicas da cidade; os meetings de protesto, alguns dos quais meticulosamente planejados; a fundação de congregações associativas; a organização de partidos políticos de pequena envergadura; a criação de clubes e centros políticos, entre outras formas de ação e participação política, eram utilizadas difusamente por variados agentes sociais. Principalmente a criação de pequenos jornais, agremiações e pequenos partidos políticos, ainda que alguns tivessem vida muito efêmera, constituía uma forma de participação regularmente praticada na época, pelo menos na capital federal (Hahner, 1976: 137). Eram manifestações de estratégias ativistas que tinham como objetivo a intervenção na política institucional.

As atuações e os meios de propagação de idéias de que os restauradores e os jacobinos faziam uso oferecem um panorama do grau de politização da primeira década republicana. Suas estratégias de ação evidenciam como atores polí- 
ticos construíam e comunicavam suas idéias políticas e buscavam, por diferentes brechas, intervir nas resoluções governamentais. Desse modo, seus ativismos nos permitem tracejar a tônica multicor e multifária desse contexto histórico de consolidação e implementação do regime republicano brasileiro.

Notas

1. A noção de que os primeiros anos republicanos demandaram uma aprendizagem já se encontra em algumas obras de Angela de Castro Gomes (1988: 19-22), que fala do "experimento republicano" e de "experiências" (2002: 21). Ver também o trabalho de Marcelo de Souza Magalhães (2005: 285-286).

2. Delimitamos a conjuntura de transição entre as presidências militar e civil como o período iniciado em meados de 1893 , com os arranjos políticos para a sucessão de Floriano que geraram diferentes expectativas nos diversos atores, $\mathrm{e}$ encerrado em outubro de 1897, com a vitória do governo sobre o movimento de Canudos. A esfera de ação de Prudente de Moraes foi ampliada por essa vitória, que reduziu o espaço dos militares do Exército no campo político-institucional, e foi ainda mais alargada após o atentado frustrado à sua vida em 5 de novembro do mesmo ano, que lhe deu a oportunidade de conter os últimos focos oposicionistas.

3. Nem todos os monarquistas eram restauradores. Estes eram os que se envolviam em alguma forma de atuação política inclinada à reinstalação monárquica, ou ao menos em uma atividade propagandista restauradora. Eram chamados pejorativamente por seus adversários políticos, entre os quais os jacobinos, de "sebastianistas", apodo que recusavam. A maioria recusava até mesmo o epíteto de restauradores, termo utilizado neste artigo apenas para diferenciar os monarquistas ativistas daqueles que também eram monarquistas, mas não se esforçavam politicamente pelo regresso monárquico. A identificação dos restauradores com os que esperavam o retorno de D. Sebastião, o rei desaparecido em África na batalha de Alcácer-Quibir, era uma tentativa discursiva de seus adversários de apontar a inexeqüibilidade de seu propósito.

4. Assinaram o documento João Alfredo Correa de Oliveira, o visconde de Ouro Preto (Afonso Celso de Assis Figueiredo), Domingos de Andrade Figueira, Joaquim Nabuco, Carlos de Laet, Lafayette Rodrigues Pereira e Carlos Afonso de Assis Figueiredo. Segundo o manifesto, o Diretório Central do Partido Monarquista de S. Paulo era composto pelos seguintes membros: João Mendes de Almeida, Eduardo da Silva Prado, Francisco Antonio de Queiroz, conselheiro Bento Francisco de Paula Souza, Antonio Ferreira de Castilho e Rafael Correa da Silva Sobrinho. O manifesto e o breve texto do redator do Fornal do Commercio foram reproduzidos na Gazeta de Noticias de 13/1/1896 sob o título "Partido Monarquista".

5. Segundo Janotti (1986: 117), a montagem das oficinas do jornal Liberdade coube ao visconde de Ouro Preto, tendo sido o restante do capital 
integralizado por outros interessados, como o coronel Gentil de Castro.

Em razão dos desentendimentos entre os acionistas, a folha em sua fase final foi praticamente sustentada por esses dois ativistas. Para esse fim, Gentil de Castro adquiriu a Gazeta da Tarde, transformando-a também em uma folha restauradora. Com os lucros obtidos com a publicação, sustentou o Liberdade até o empastelamento deste, em março de 1897.

6. Nem todo florianista era ou se dizia um jacobino, embora todos os jacobinos fossem ardentes florianistas. Jacobinos, florianistas e castilhistas eram designações de certo modo intercambiáveis entre os contemporâneos. Mais específica, a última era geralmente utilizada em relação aos florianistas sulinos, defensores da política de Júlio de Castilhos, e aos voluntários dos batalhões patrióticos que haviam combatido ou ainda permaneciam nos estados do sul do país.

7. A carta, intitulada "Testamento político", foi inteiramente transcrita em O Facobino de $29 / 9 / 1895$, p. 2 . O trecho em que Floriano Peixoto se dirigia especificamente à mocidade, impingindo-lhe um dever cívico, era o seguinte: "A vós, que sois moços e trazeis vivo e ardente no coração o amor da Pátria e da República, a vós corre o dever de ampará-la e defendê-la dos ataques dos inimigos. Diz-se e repete-se que ela está consolidada e não corre perigo. Não vos fieis nisso, nem vos deixeis apanhar de surpresa. $\mathrm{O}$ fermento da restauração agita-se em uma ação lenta, mas contínua e surda. Alerta! pois".

8. Ver matérias sob o título "Partido Republicano Nacional" a partir de 10 de agosto de 1895 em O Nacional, geralmente na p. 1 .

9. Assinaram primeiramente o manifesto Martiniano Brandão, Julio da Silveira Lobo, Dr. Carlos Costa, Annibal
Mascarenhas e Lindolpho Azevedo. Ver "Partido Republicano Nacional:

Manifesto", O Nacional, 3/3/1896, p. 1-2.

10. "Partido Republicano Nacional", O Nacional, 8/5/1896, p. 2.

11. Na Gazeta de Noticias: "Questões do dia: o Partido Nacional”, 17/6/1897, p. 1; "Partido Republicano Nacional: o diretório central aos seus associados", 19/6/1897, p. 2; "Cousas políticas", 21/6/1897, p. 1.

12. Na Gazeta de Noticias, "Centro Monarquista de S. Paulo", 1/11/1896, p. 2 e "Habeas corpus dos monarquistas de $S$. Paulo", 15/11/1896, p. 1.

13. “Que infelicidade!”, O Facobino, 23/1/1897, n. 81, p. 1.

14. "O Sr. presidente da República", Gazeta de Noticias, 4/3/1897, p. 1. "Infeliz Pátria!”, O Facobino, 6/3/1897, n. 87, p. 1.

15. "No Clube Militar", Gazeta de Noticias, 7/3/1897, p. 1.

16. Gazeta de Noticias, 8/3/1897, p. 1.

17. Gazeta de Noticias, edição de 9/3/1897 e seguintes, p.1.

18. Em O Facobino, "Às armas, Brasileiros!", 20/2/1896, n. 85, p. 2; “Infeliz Pátria!", 6/3/1897, n. 87, p. 1; "Mais um herói morto!", 13/3/1897, n. 88, p. 3; editorial sem título e "Está tudo errado!", 27/3/1897, n. 90, capa e p. 2, e "República ou morte!", 10/4/1897, n. 92, p.1.

19. "Aos patriotas", O Facobino, 8/5/1897, n. 96, p.1.

20. "O atentado", Gazeta de Noticias, 6/11/1897, p. 1.

21. "A imprensa", "As arruaças" e "O atentado", Gazeta de Noticias, 8/11/1897, p. 1 .

22. Na Gazeta de Noticias, "O atentado: na Câmara - o estado de sítio", 9, 10, 11 e 12/11/1897, p. 1, e "Estado de sítio", 13/11/1897, p. 1 . 
23. "Tentativa de evasão", Gazeta de Noticias, 13/11/1897, p. 1.

Referências bibliográficas

FLORES, Élio Chaves. 2003. A consolidação da República: rebeliões de ordem e progresso. In: Ferreira, Jorge \& Delgado, Lucilia de Almeida Neves (orgs.). O Brasil Republicano - O tempo do liberalismo excludente: $d a$ Proclamação da República à Revolução de 1930. Rio de Janeiro: Civilização Brasileira. Livro 1, p. 45-88.

GOMES, Angela de Castro. 1988. A invenção do trabalhismo. São Paulo: Vértice/ Rio de Janeiro: Iuperj.

- 2002. O 15 de novembro. In: _; PANDOLFI, Dulce Chaves \& ALBERTI, Verena (coord.). A República no Brasil. Rio de Janeiro: Nova Fronteira, CPDOC/FGV, p. 12-30.

\& FERREIRA, Marieta de Moraes. 1989. Primeira República: um balanço historiográfico. Estudos Históricos, Rio de Janeiro, vol. 2, n. 4.

HAHNER, June. 1976. Jacobinos versus galegos. Urban radicals versus portuguese immigrants in Rio de Janeiro in the 1890. Fournal of Interamerican Studies and World Affairs, 18 , n. 2.

JANOTTI, Maria de Lourdes Mônaco. 1986. Os subversivos da República. São Paulo: Brasiliense.

1990. A República: oposições e consolidações. In: LAPA, José Roberto do Amaral (org.). História política da República: coletânea de ensaios inéditos comemorativa do centenário da República.
24. "Batalhão Tiradentes", Gazeta de

Noticias, 30/11/1894, p. 1.

Campinas: Papirus. Coleção Tempo e Memória, v. 2.

KOSELLECK, Reinhart. 1992. Uma história dos conceitos: problemas teóricos e práticos. Tradução, transcrição e edição de Manoel Luís Salgado Guimarães. Estudos Históricos, Rio de Janeiro, vol. 5, n. 10.

MAGALHÃES, Marcelo de Souza. 2005. Repensando política e cultura no início da República: existe uma cultura política carioca?. In: SOIHET, Rachel; BICALHO, Maria Fernanda B. e GOUVÊA, Maria de Fátima. Culturas políticas: ensaios de história cultural, história política e ensino da história. Rio de Janeiro: Mauad, p. 285-303.

MCCANN, Frank. 1971. Review: Civilian-Military Relations in Brazil: 1889-1898, by June Hahner. The American Historical Review, vol. 76, n. 4.

MUZZI, Amanda da Silva. 2006. Os jacobinos e a oposição a Prudente de Moraes na transição entre as presidências militar e civil-1893-1897. PUC-Rio, dissertação de Mestrado em História.

NEVES, Margarida de Souza. 2003. Os cenários da República: o Brasil na virada do século XIX para o século XX. In: FERREIRA, Jorge \& DELGADO, Lucilia de Almeida Neves (orgs.). O Brasil Republicano-O tempo do liberalismo excludente: $d a$ Proclamação da República à Revolução de 1930. Rio de Janeiro: Civilização Brasileira. Livro 1. 
PAMPLONA, Marco Antonio Villela. 2003. Revoltas, repúblicas e cidadania: Nova York e Rio de Faneiro na consolidação da ordem republicana. Rio de Janeiro: Record.

QUEIROZ, Suely Robles Reis de. 1986. Os radicais da República. Facobinismo: ideologia e ação (1893-1897). São Paulo: Brasiliense.

1990. O Jacobinismo na historiografia republicana. In: LAPA, José Roberto do Amaral (org.). História política da República: coletânea de ensaios inéditos comemorativa do centenário da República. Campinas: Papirus. Coleção Tempo e Memória, v. 2.

SILVA, Ana Carolina Feracin da. 2001. Entre a pena e a espada: literatos $e$ jacobinos nos primeiros anos da República
(1889-1895). Unicamp, dissertação de Mestrado em História.

SIMAS, Luiz Antônio. 1994. O evangelho segundo os jacobinos: Floriano Peixoto e o mito do Salvador da República Brasileira. UFRJ, dissertação de Mestrado em História do Brasil.

SIQUEIRA, Carla Vieira de. 1995. A imprensa comemora a República: o 15 de novembro nos jornais cariocas 1890/1922. PUC-Rio, dissertação de Mestrado em História.

SODRÉ, Nelson Werneck. 1966. História da imprensa no Brasil. Rio de Janeiro: Civilização Brasileira.

VENEU, Marcos Guedes. 1987. Enferrujando o sonho: partidos e eleições no Rio de Janeiro, 1889-1895. Dados - Revista de Ciências Sociais. Rio de Janeiro, vol. 30, n. 1.

\section{Resumo}

Neste artigo comparamos as experiências de monarquistas restauradores e jacobinos, dois grupos políticos rivais durante a primeira década republicana, enfatizando suas atuações na conjuntura de transição entre a presidência militar de Floriano Peixoto e a civil de Prudente de Moraes, ou seja, no período entre 1893 e 1897. Suas demandas e estratégias de ação evidenciam como atores políticos construíam e comunicavam suas idéias e buscavam, por diferentes brechas, intervir nas resoluções governamentais. Assim, traçamos um breve panorama do grau de politização da primeira década republicana, dimensionando suas respectivas atuações.

Palavras-chave: primeira década republicana; monarquistas restauradores; jacobinos; atuações políticas

\section{Abstract}

In this article we compare the experiences of two rival political groups, pro-restoration monarchists and jacobins, during the first republican decade in Brazil, mainly in the transition period of the military government of Floriano Peixoto to the civilian one of Prudente de Moraes, between 1893 and 1897. The claims and strategies of these groups show how political actors 
built and communicated their ideas, and tried to interfere in governmental resolutions. By describing their performances we try to show the degree of political activism in this first republican decade.

Key words: the first decade of Brazilian Republic; pro-restoration monarchists; jacobins; political performances

\section{Résumé}

Dans cet article on compare les expériences de deux groupes politiques rivaux, les monarchistes restaurateurs et les jacobins, pendant la première décenie de la République au Brésil, en examinant leurs actions pendant la transition de la présidence militaire de Floriano Peixoto à la présidence civile de Prudente de Moraes, entre les anées de 1893 et 1897. Leurs demandes et stratégies d'action montrent comment les agents politiques construisaient et communiquaient leurs idées, e comment ils cherchaient à intervenir dans les résolutions gouvernementales. En décrivant ces actions, nous dressons un bref panorama du dégré de politisation de cette première décenie républicaine.

Mots-clés: première décénie républicaine au Brésil; monarchistes restaurateurs; jacobins; actions politiques 